\title{
Recent Advances in Organocatalyzed Domino C-C Bond-Forming Reactions
}

\author{
Cleo S. Evans and Lindsey O. Davis * \\ Department of Chemistry and Biochemistry, Berry College, P.O. Box 495016, Mt. Berry, GA 30149, USA; \\ cleo.evans@vikings.berry.edu \\ * Correspondence: ldavis@berry.edu; Tel.: +1-706-236-2237
}

Received: 11 December 2017; Accepted: 22 December 2017; Published: 23 December 2017

\begin{abstract}
Reactions that form a $\mathrm{C}-\mathrm{C}$ bond make up a foundational pillar of synthetic organic chemistry. In addition, organocatalysis has emerged as an easy, environmentally-friendly way to promote this type of bond formation. Since around 2000, organocatalysts have been used in a variety of $\mathrm{C}-\mathrm{C}$ bond-forming reactions including Michael and aldol additions, Mannich-type reactions, and Diels-Alder reactions, to name a few. Many of these methodologies have been refined and further developed to include cascade and domino processes. This review will focus on recent advances in this area with an emphasis on methodologies having applications in the synthesis of biologically-significant compounds.
\end{abstract}

Keywords: organocatalysis; domino; tandem; Henry; aldol; Mannich

\section{Introduction}

Reactions that form carbon-carbon bonds are an important tool for a synthetic organic chemist. Since the early 2000s, the field of organocatalysis has developed as an attractive alternative to traditional metal Lewis acid catalysis [1]. As the field of organocatalysis has matured, chemists have found methods for many organocatalyzed domino processes allowing for the synthesis of complex molecules in an efficient manner [2]. The aim of this mini-review is to highlight the work done over the past two years in organocatalyzed domino processes that involve the formation of a carbon-carbon bond. In particular, we will focus on reports that have led to the synthesis of compounds with biological and medicinal significance. Also, we have tried to avoid reviewing literature that has been recently cited elsewhere [3].

\section{Mannich}

The Mannich reaction is an extensively-studied and significant tool in the synthesis of $\beta$-amino ketones, sometimes referred to as Mannich bases [4,5]. Organocatalyzed, asymmetric variants of this reaction were developed in the early 2000s, primarily utilizing proline and its derivatives as the organocatalyst [6], although Cinchona alkaloids [7,8], (DHQD) $)_{2}$-based catalysts (dihydroquinidine) [9], thioureas [10], and phosphoric acid derivatives [11] have been employed as well. Tandem organocatalyzed Mannich reactions have been reported in the synthesis of biologically-significant compounds [12], but many of these reactions have been reviewed elsewhere [13]. The focus of this section will be tandem Mannich reactions reported between 2016 and late 2017.

Spirocyclic oxindole scaffolds are found in a variety of biological molecules [14-18]. $\mathrm{Yu}$ and co-workers recently reported a synthesis of spirooxindole benzoquinolizines utilizing a Michael-Mannich-hemiaminalization-dehydration cascade (Scheme 1) [19]. The Jørgensen-Hayashi catalyst (1) was used to catalyze the reaction and $10 \mathrm{~mol} \% \mathrm{PhCO}_{2} \mathrm{H}$ was used an additive. After screening various bases for the Mannich reaction, DABCO (1,4-diazabicyclo[2.2.2]octane) was 
chosen as the best base, as compared to DIPEA ( $N$, N-diisopropylethylamine), $\mathrm{K}_{2} \mathrm{CO}_{3}$, or $\mathrm{PPh}_{3}$ among others. The scope of the reaction, made up of 19 examples, included both electron-donating and electron-withdrawing groups at the phenyl ring of the imine, although no strong electron-withdrawing groups were employed. In addition, a gram scale synthesis was achieved with good yield (65\% yield), showing promise for this reaction methodology to be used in commercial production.

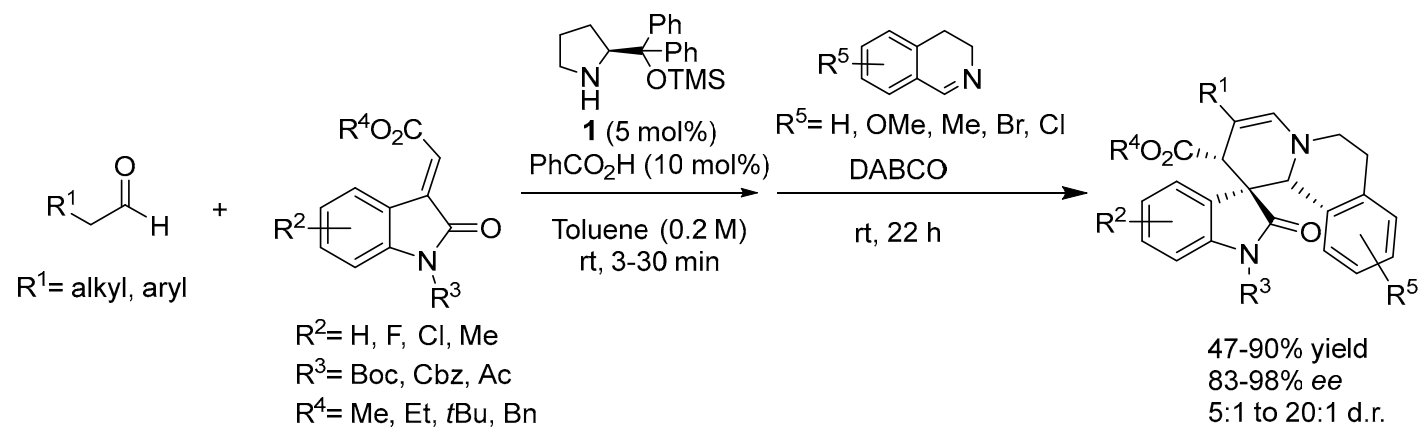

Scheme 1. Michael-Mannich-hemiaminalization-dehydration cascade.

Catalyst 1 has also recently been used to catalyze a Michael/Mannich [3 + 2] cycloaddition cascade reaction between $\alpha$ - $\beta$-unsaturated aldehydes and trifluoromethyl-substituted iminomalonates to form trifluoromethyl-substituted pyrrolidines (Scheme 2) [20].

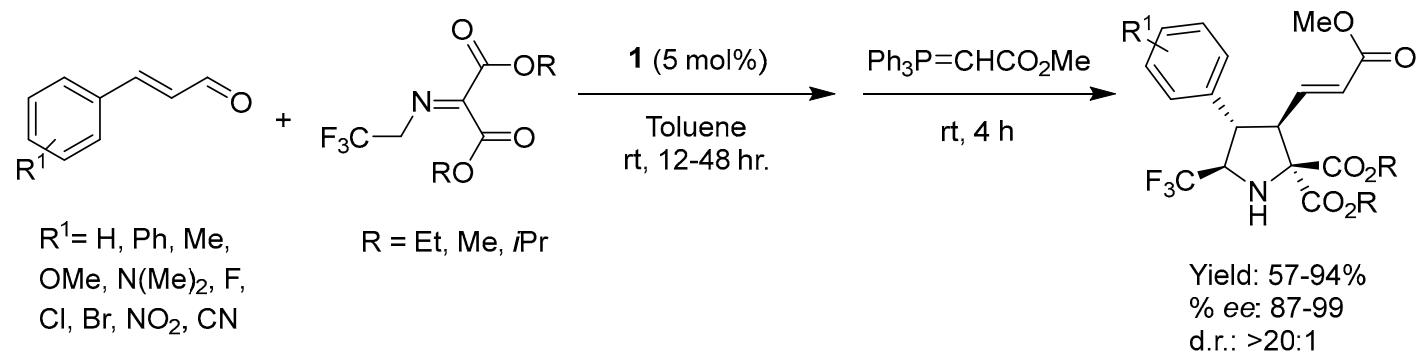

Scheme 2. Michael-Mannich cascade followed by Wittig olefination.

Substituted pyrrolidines are found in many bioactive natural products and pharmaceutical agents [21,22]. Particularly, the addition of the trifluoromethyl group to these pyrrolidines makes them attractive targets for synthetic organic chemists $[23,24]$. This methodology provides a synthesis of chiral trifluoromethylated pyrrolidines with good yield and excellent diastereoselectivity and enantioselectivity. In addition, the reaction proceeded smoothly with electron-withdrawing and electron-donating groups appended to the $\alpha, \beta$-unsaturated aldehyde.

In addition to proline-derived organocatalysts, urea-derived organocatalysts have been used in domino reactions. Zhou and co-workers recently developed an asymmetric Mukaiyama-Mannich reaction between fluorinated silyl enol ethers and ketimines catalyzed by a hydroquinine derived bifunctional urea catalyst 2 (Scheme 3) [25]. 
<smiles>[R2]OC1=NS(=O)(=O)c2ccccc21</smiles>

$0.25 \mathrm{mmol}$

$\mathrm{R}^{1}=\mathrm{H}, \mathrm{Me}, \mathrm{OMe}$,

$\mathrm{OCF}_{3}, \mathrm{~F}, \mathrm{Cl}, \mathrm{CF}_{3}$ $\mathrm{R}^{2}=\mathrm{Et}, \mathrm{Me}$

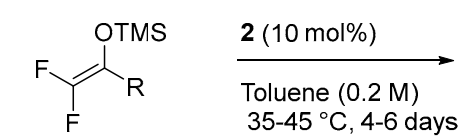

$0.50 \mathrm{mmol}$

$\mathrm{R}=\mathrm{Ph}, 4-\mathrm{MeOC}_{6} \mathrm{H}_{4}$,

$4-\mathrm{ClC}_{6} \mathrm{H}_{4}, \mathrm{CH}_{2} \mathrm{Bn}$

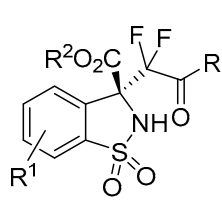

Yield: $61-99 \%$

$\%$ ee: $87-94$

d. $r .:>20: 1$

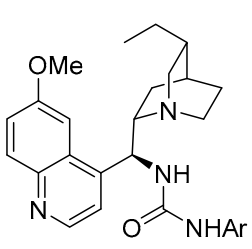

$\mathrm{Ar}=3,5-\left(\mathrm{CF}_{3}\right)_{2} \mathrm{C}_{6} \mathrm{H}_{3}$

2

Scheme 3. Formation of fluorinated benzosultam derivatives.

Benzosultam based $\mathrm{C}^{\alpha}$-tetrasubstituted $\alpha$-amino acid derivatives, the products of this reaction, have been shown as valuable chiral auxiliaries and reagents [26-29] and found in biologically-significant compounds [30,31]. Through a catalyst screening, the authors determined that both $\mathrm{N}-\mathrm{H}$ bonds of the urea catalyst were necessary for achieving enantiofacial control. The substrate scope included difluoroenoxysilanes with appended electron-donating and electron-withdrawing groups; however, aliphatic difluorinated enol silyl ethers were not reactive enough to give a substantial amount of product. The reaction was scalable to a $3.0 \mathrm{mmol}$ scale, showing the potential of this methodology for practical synthetic purposes. In addition to difluorinated substrates, monofluorinated enol silyl ethers were also successful substrates in this reaction, producing monofluorinated benzosultam products in high yield (78-99\% yield) and good selectivity ( $>20: 1 \mathrm{dr}$ and $90-92 \% e e$ ).

\section{Henry Reactions}

The nitro-aldol reaction, or Henry reaction, has been established as a powerful methodology for the formation of carbon-carbon bonds between nitroalkenes and ketones or aldehydes [32-34]. Though the Henry reaction was discovered in 1896, a chiral variant was not developed until the 1990s [35,36]. Asymmetric organocatalysts were employed in both the Henry reaction and aza-Henry reaction in the early 2000s [37,38]. Since then, researchers have sought to expand the reaction scope and reaction conditions, testing new chiral organocatalysts such as squaramide [39], thiourea derivatives [40], proline derivatives [41], and bipyridine derivatives [42]. Like the aldol reaction, Henry reactions are often used in tandem with Michael reactions [40,41,43,44]. The following syntheses involve Michael-Henry or double-Michael-Henry cascades that proceed via different chiral organocatalysts to form new ring systems with multiple stereogenic centers.

Xie and co-workers reported diastereodivergent syntheses of $2 \mathrm{H}$-thiopyrano[2,3b]quinolones with three contiguous stereocenters via a domino Michael-Henry reaction (Scheme 4) [45].

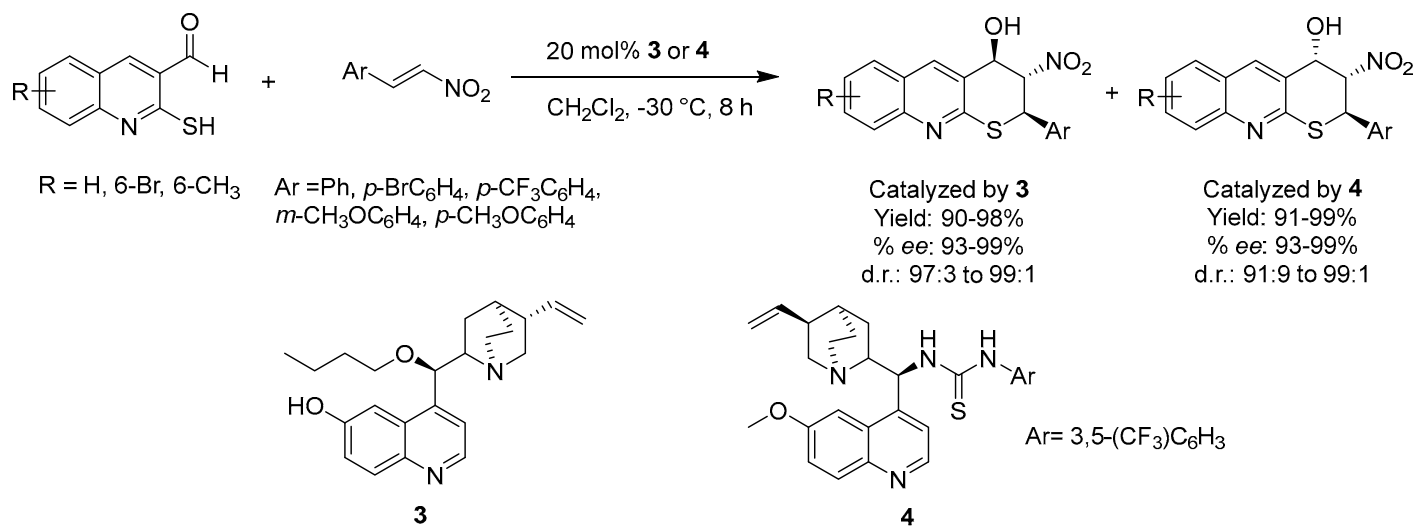

Scheme 4. Synthesis of chiral functionalized quinolines via Michael-Henry reaction. 
Both the quinolone ring and thiopyran functional group have potential as biological and pharmaceutical targets [46-51]. Quinoline-derived organocatalysts had previously been identified as successful catalysts for conjugate additions [52-54]. Unsurprisingly, the authors could identify two viable catalysts for the tandem Michael-Henry reaction, quinolines 3 and 4 . They discovered that the diastereoselectivity of these catalysts were complementary to each other, where catalyst 3 produced the 1,2-anti diastereomer and catalyst 4 gave the 1,2-syn diastereomer. Using a starting material previously synthesized by the group, O-thiocyanato-(E)-cinnamaldehyde [55], nitroolefin, and two different quinoline-derived organocatalysts, the group was able to obtain excellent yields, enantioselectivity, and diastereoselectivity in $8 \mathrm{~h}$ at $-30{ }^{\circ} \mathrm{C}$ using $20 \mathrm{~mol} \%$ of catalyst and two equivalents of nitroolefin.

Liu and coworkers also used a bifunctional organocatalyst, guanidinium derivative 5 , in a Michael/Michael/Henry cascade (Scheme 5) [56]. Remarkably, this is the first example of a single chiral organocatalyst being employed to create cyclohexanes with six vicinal stereogenic centers. Prior to this publication, a combination of organocatalysts [57] or a Lewis acid catalyst with an organic base co-catalysts [58] were required to achieve this transformation.
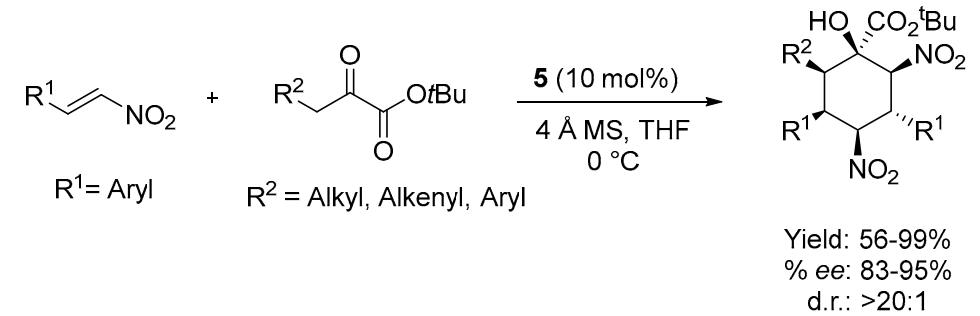

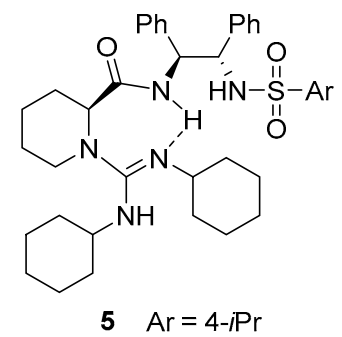

$5 \mathrm{Ar}=4-\mathrm{PPr}$

Scheme 5. Synthesis of chiral cyclohexane via Michael/Michael/Henry cascade.

The reaction tolerated a variety of electron-donating and electron-withdrawing groups on the aryl substituent of the nitroalkene, although the electronic characteristics played a role in the yield. Those aryl groups with electron-withdrawing substituents typically gave higher yields of the cyclohexane product. The scope of the reaction with respect to the $\alpha$-ketoester included alkyl, alkenyl, and aryl substituents with little effect on the yield or selectivity. While the utility of the products has not been fully realized, this report provides a remarkable example of an organocatalyzed domino reaction.

Another noteworthy example of an organocatalyzed domino Henry reaction was recently reported by Lin and co-workers. A squaramide derivative 6 was found to catalyze the first tandem vinylogous Michael (VMA)/Henry reaction involving a ketone moiety to synthesize tetrahydrofluoren-9-ones (Scheme 6) [59]. This class of compound was incorporated into medicines used to treat and reduce brain and spinal injuries as early as the 1970s, and is still pharmaceutically relevant [60]. With a combined 23 examples, the scope of this reaction included nitroalkenes with aryl rings with various electron-donating and electron-withdrawing substituents. The 1,3-indandione-derived substrate typically tolerated aryl and alkyl groups. 


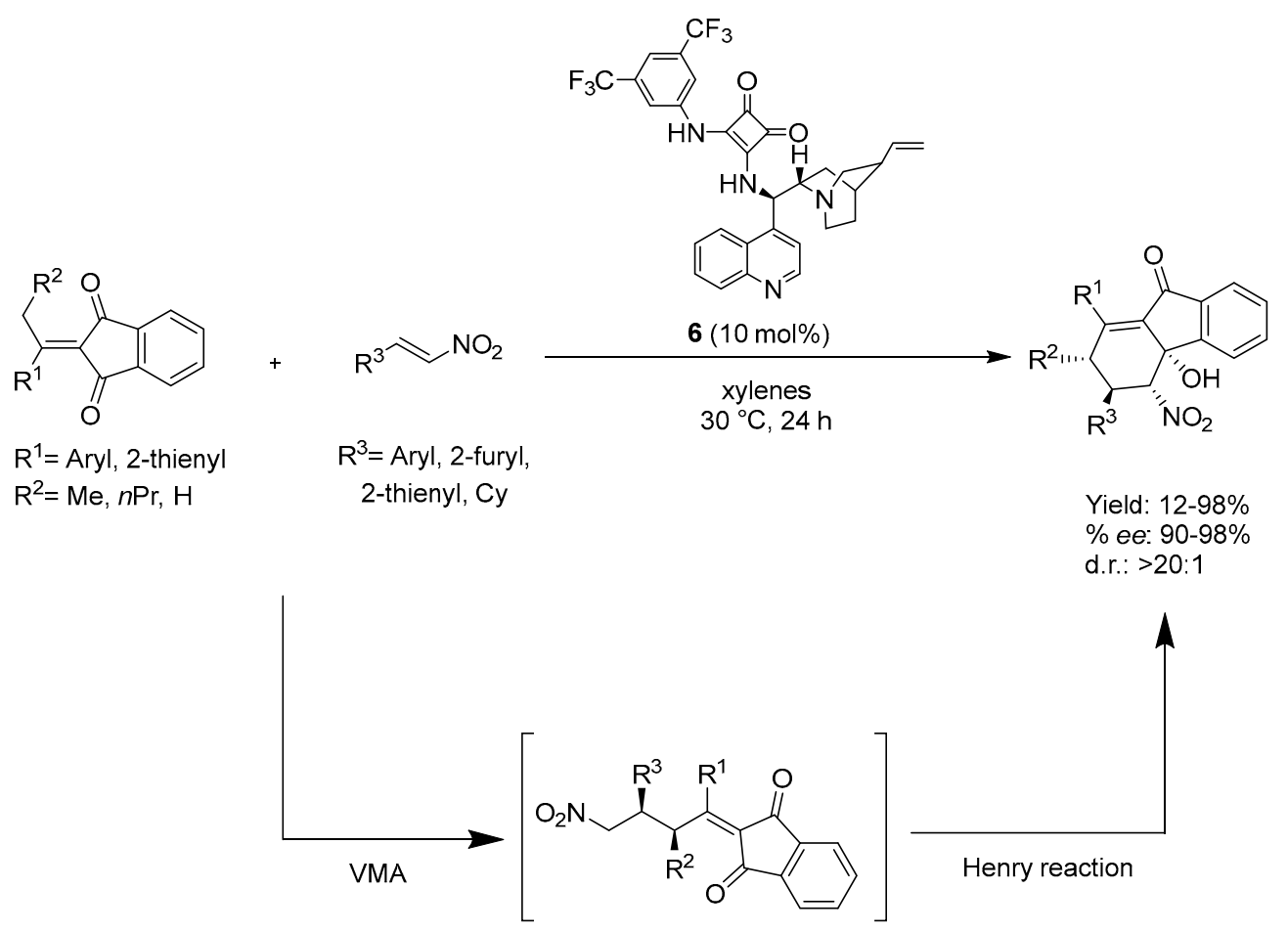

Scheme 6. Synthesis of tetrahydrofluoren-9-ones via Michael/Michael/Henry cascade.

In addition to a wide scope, the authors were also able to provide preliminary results that showed the generality of the indandione-derived pronucleophiles. Another Michael acceptor, a oxindole derivative (Figure 1) was used in this reaction, and with slightly modified reaction conditions, the products were made in high yield (92-98\%) and moderate enantioselectivity (81-83\%).<smiles>CCOC(=O)/C=C1/C(=O)N(C(=O)OC(C)(C)C)c2ccccc21</smiles>

Figure 1. An oxindole derivative used as a Michael acceptor in a VMA/Aldol reaction cascade.

Hong et al. constructed highly functionalized Hajos-Parrish-ketones (HPKs) containing five to six contiguous stereogenic centers through an organocatalytic enantioselective Michael/Michael/Henry reaction (Scheme 7) [61]. HPKs have been used as important synthons for a variety of natural products [62], and are one of the historical origins of organocatalysis [63,64]. The Jorgensen-Hayashi catalyst was used in a biphasic system of water:acetonitrile at 2:1 over a seven to fourteen day period at room temperature. The aqueous phase allowed for the necessary dissolution of cyclopentadione reagent. A variety of HPKs were synthesized (10 examples) with moderate to good yield and excellent enantioselectivity. 


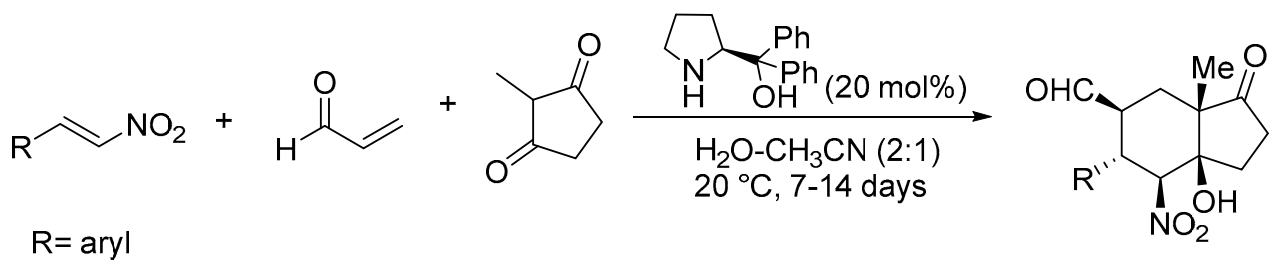

Yield: $58-75 \%$

$\%$ ee: $90-94 \%$

Scheme 7. Synthesis of Hajos-Parrish-type ketones via double-Michael/Henry reaction.

It is noteworthy that the synthesized HPKs have five to six contiguous stereocenters and two quaternary carbons. This report provides a hallmark example of the utility of domino reactions to create complex products efficiently.

\section{Aldol Reactions}

The aldol reaction is arguably one of the most researched and versatile $\mathrm{C}-\mathrm{C}$ bond-forming reactions in all of organic chemistry [65-67]. Not surprisingly, there are many examples of organocatalyzed aldol reactions, typically catalyzed by proline and its derivatives [68-70]. Aldol reactions have commonly been incorporated in domino reactions and reviewed somewhat recently [71,72]; therefore, we will focus on reports from this year only.

Rios and co-workers developed a double Michael addition to $\alpha, \beta$-unsaturated aldehydes, followed by an intramolecular aldol reaction to synthesize pyridine derivatives using a chiral secondary amine catalyst 1 (Scheme 8) [73].

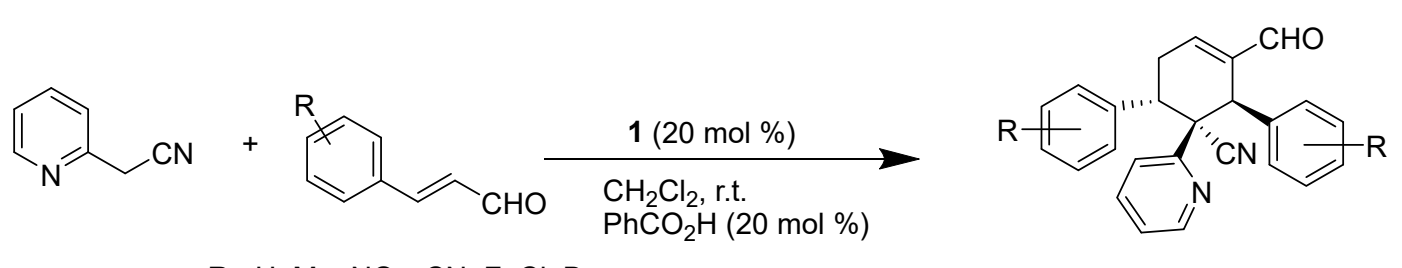

$\mathrm{R}=\mathrm{H}, \mathrm{Me}, \mathrm{NO}_{2}, \mathrm{CN}, \mathrm{F}, \mathrm{Cl}, \mathrm{Br}$

$$
\begin{aligned}
& \text { 33-72\% yield } \\
& 3: 1 \text { to } 6: 1 d r \\
& 87-99 \% \text { ee }
\end{aligned}
$$

Scheme 8. Synthesis of pyridine derivative by Michael/Michael/Aldol reaction.

Remarkably, this cascade resulted in the formation of three $\mathrm{C}-\mathrm{C}$ bonds with moderate yield and diastereoselectivity and excellent enantiopurity. Enals with appended electron-withdrawing groups (e.g., $p$-nitro, $p$-cyano) were excellent substrates, whereas enal substrates with substituted halogen atoms provided the final products in only moderate yield (63-72\%). Unfortunately, if an electron-donating group such as an aliphatic aldehyde was employed as the substrate, the reaction gave a complex mixture. Nevertheless, this report provides an excellent example of the power of the aldol reaction in a domino process.

The (S)-TMS-diarylprolinol catalyst $\mathbf{1}$ has also been used recently to catalyze a Michael/Michael/aldol condensation to provide tricyclic chromanes bearing four contiguous stereogenic centers, one of which is tetrasubstituted (Scheme 9) [74]. Chromanes are a commonly-found scaffold in a variety of natural products, some of which have anticancer and antibacterial $[75,76]$, antifungal [77], analgesic [78], and antimalarial properties [79,80]. This methodology has a large reaction scope. Nitrochromenes with appended electron-neutral $(\mathrm{H})$, electron-donating, or electron-withdrawing groups at the $\mathrm{C} 6$ or $\mathrm{C} 7$ position were excellent substrates in this reaction. In addition, dihalogenated 3-nitro- $2 \mathrm{H}$-chromenes at the $\mathrm{C} 6$ and $\mathrm{C} 8$ positions provided products 
in moderate yield and excellent enantioselectivity. Many aliphatic aldehydes were also used as substrates, with moderate yield of chromene products; however, isovaleraldehyde and tert-butyl acetaldehyde were not successful substrates even after five days of reaction. The authors also screened different $\alpha, \beta$-unsaturated aldehydes, where aliphatic aldehydes (e.g., acrylaldehyde) provided the desired product in good yield and excellent diastereoselectivity and enantioselectivity. The selectivity remained high for aromatic $\alpha, \beta$-unsaturated aldehydes bearing electron-neutral, electron-donating, and electron-withdrawing groups. It is noteworthy that this methodology was shown to be viable on a gram scale, demonstrating the applicability of this protocol.

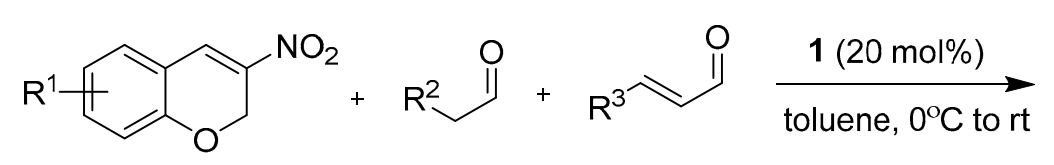

$\mathrm{R}^{1}=\mathrm{H}, \mathrm{Cl}, \mathrm{Br}, \mathrm{F}, \quad \mathrm{R}^{2}=$ Alkyl $\quad \mathrm{R}^{3}=\mathrm{H}, \mathrm{Ar}, \mathrm{Ph}$ $\mathrm{NO}_{2}, \mathrm{CH}_{3}, \mathrm{OCH}_{3}$<smiles>[R]C1=CC(C=O)C([R])[C@]2([N+](=O)[O-])COc3ccccc3[C@H]12</smiles>

$20-66 \%$ yield $>20: 1 \mathrm{dr}$ $99 \%$ ee

Scheme 9. A Michael-Michael-aldol condensation to produce chromanes.

Pan and co-workers recently reported a method for the synthesis of 3-acyloxypyrazoles from unsaturated pyrazolones and $\alpha$-nitroketones through an asymmetric Michael/Hemiketalization/retro-aldol reaction to product 3-acyloxy pyrazoles (Scheme 10) [81].<smiles>[R]C=C1C(=O)N([R2])N=C1C</smiles>

$\mathrm{R}^{1}, \mathrm{R}^{2}=\mathrm{Ar}$

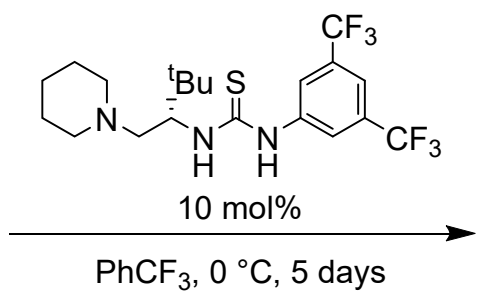

$\mathrm{R}^{3}=\mathrm{Ar}, \mathrm{HetAr}, \mathrm{Alk}$<smiles>[R]C(=O)C[N+](=O)[O-]</smiles>

列, 5 days<smiles>[R]Oc1c(C([R])C[N+]([R])=O)c(C)nn1[R]</smiles>

$57-94 \%$ yield $85-99 \%$ ee

Scheme 10. Synthesis of 3-acyloxy pyrazoles through Michael/Hemiketalization/retro-aldol.

Pyrazoles are particularly important nitrogen containing motifs because they are found in a wide variety of bioactive compounds [82,83]. A wide variety of pyrazolones having different benzylidene substituents were tolerated in this reaction. Both electron-donating and electron-withdrawing groups at the ortho-, meta-, and para-position of the aryl group afforded the pyrazoles in excellent yields and enantioselectivities. In addition, various pyrazolones with N-substitutions (e.g., 4- $\mathrm{MeC}_{6} \mathrm{H}_{4}$ ) were also successful substrates with yields of pyrazoles ranging from $81 \%$ to $93 \%$ with excellent enantioselectivities. The generality of the reaction was further demonstrated as the scope of nitroketones included various those with appended aryl groups, heteroaromatic rings, and alkyl groups.

\section{Other Reactions}

\subsection{Knoevenegal/Diels-Alder Reactions}

Estévez-Braun and co-workers have recently reported two examples of Knoevenegal/ Hetero-Diels-Alder domino reactions (DKHDA) in the synthesis of embelin derivatives 
(Scheme 11) [84,85]. Embelin, a biologically-active compound derived from a plant, has been reported to be a promising structural backbone for potential drug candidates [86].

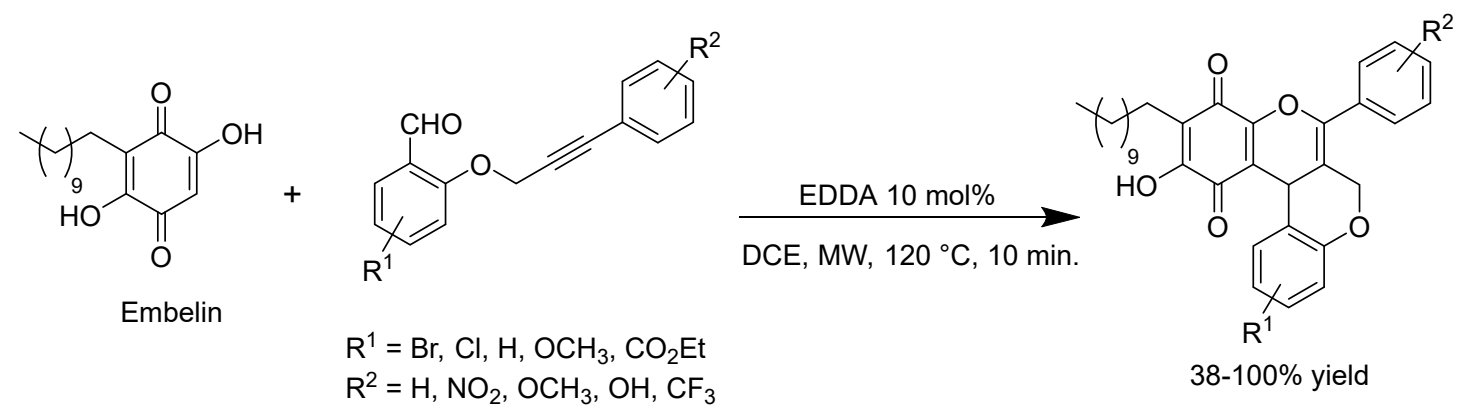

Scheme 11. Synthesis of embelin derivatives via organocatalyzed Knoevenegal/Hetero-Diels-Alder domino reactions (DKHDA) reaction.

This report is particularly significant because it is the first time intramolecular DKHDA reactions with non-terminal alkynes type $O$-(arylpropynloxy)-salicylaldehydes have been used. Thirty-five aryl-substituted alkynyl ethers were prepared using this methodology, with the majority of reactions giving moderate to high yields of product. The reaction tolerated a variety of electron-donating and electron-withdrawing groups on either aryl ring. The authors hypothesized that the added molecular complexity, introduced with ease because of the domino process, may result in more active and selective biological molecules when compared to embelin.

\subsection{Wittig Reactions}

Organocatalyzed Michael/Wittig reactions have been used in the synthesis of pyrazoles [87] and trisubstituted cyclohexene carboxylates [88]. Recently, Ghorai and co-workers reported the use of bifunctional squaramide/thiourea catalyst in a Wittig/oxa-Michael reaction to synthesize benzoxaborole derivatives (Scheme 12) [89].

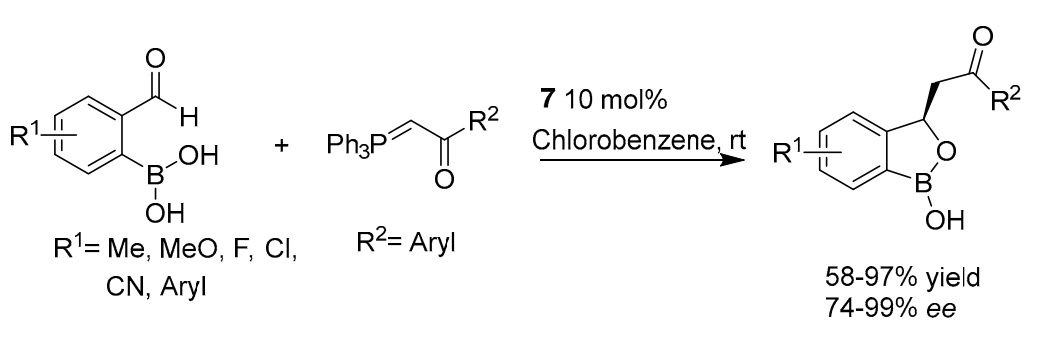

$74-99 \%$ ee

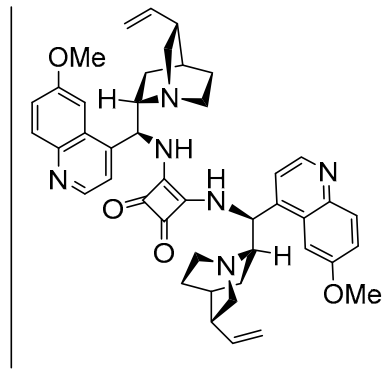

7

Scheme 12. Reaction scope of $o$-formyl aryl boronic acids.

Benzoxaboroles have been shown to have many potential pharmaceutical applications because of their anti-parasitic, antimalarial, anti-inflammatory, antibacterial, and antiviral properties [90]. The bifunctional organocatalyst is thought to coordinate to the carbonyl of the substrates through the squaramide/thiourea functional groups of the catalyst (the pull), and the tertiary nitrogen of the catalyst coordinates to the boron in the substrate providing the "push". The substitution on the aryl moiety was found to be quite general, as electron-donating and electron-withdrawing substituents worked well, resulting in the isolation of the benzoxaboroles in excellent yield and enantioselectivities. The authors also were able to use the benzoxaborles as substrates in the synthesis of chiral $\beta$-hydroxy ketones in good yield and enantioselectivity (Scheme 13). 


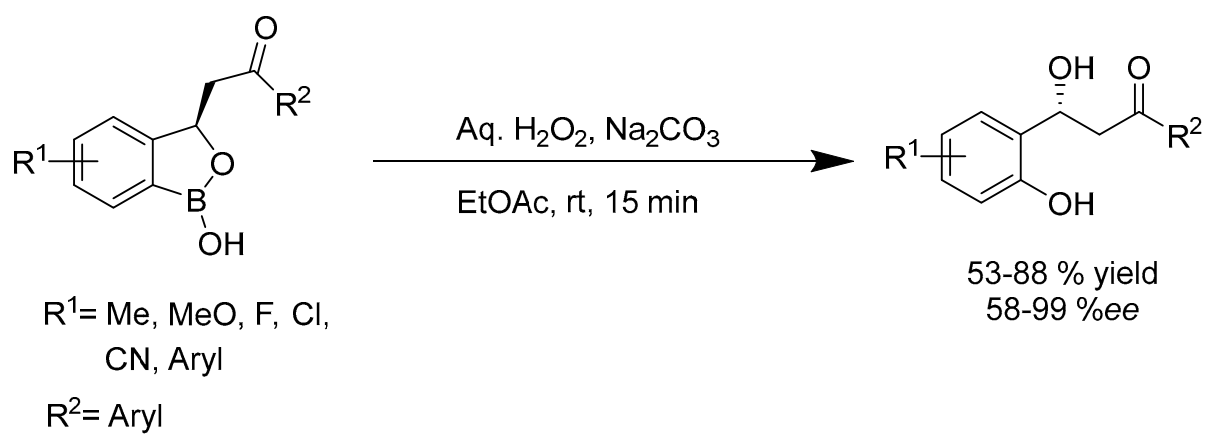

Scheme 13. Synthesis of $\beta$-hydroxy ketones.

Acknowledgments: The authors would like to acknowledge Berry College for their financial support.

Conflicts of Interest: The authors declare no conflict of interest.

\section{References}

1. Scheffler, U.; Mahrwald, R. Recent Advances in Organocatalytic Methods for Asymmetric C-C Bond Formation. Chem. Eur. J. 2013, 19, 14346-14396. [CrossRef] [PubMed]

2. Rueping, M.; Atodiresei, I. 6.13 C-C Bond Formation: Cascade or Domino Reaction. In Comprehensive Chirality; Elsevier: Amsterdam, The Netherlands, 2012; pp. 345-373, ISBN 978-0-08-095168-3.

3. Gasperi, T.; Miceli, M.; Campagne, J.-M.; Marcia de Figueiredo, R. Non-Covalent Organocatalyzed Domino Reactions Involving Oxindoles: Recent Advances. Molecules 2017, 22, 1636. [CrossRef] [PubMed]

4. Arend, M.; Westermann, B.; Risch, N. Modern Variants of the Mannich Reaction. Angew. Chem. Int. Ed. 1998, 37, 1044-1070. [CrossRef]

5. Córdova, A. The Direct Catalytic Asymmetric Mannich Reaction. Acc. Chem. Res. 2004, 37, 102-112. [CrossRef] [PubMed]

6. Verkade, J.M.M.; van Hemert, L.J.C.; Quaedflieg, P.J.L.M.; Rutjes, F.P.J.T. Organocatalysed asymmetric Mannich reactions. Chem. Soc. Rev. 2008, 37, 29-41. [CrossRef] [PubMed]

7. Li, W.; Song, B.; Bhadury, P.S.; Li, L.; Wang, Z.; Zhang, X.; Hu, D.; Chen, Z.; Zhang, Y.; Bai, S.; et al. Chiral Cinchona Alkaloid-Derived Thiourea Catalyst for Enantioselective Synthesis of Novel $\beta$-amino Esters by Mannich Reaction. Chirality 2012, 24, 223-231. [CrossRef] [PubMed]

8. Yeboah, E.M.O.; Yeboah, S.O.; Singh, G.S. Recent Applications of Cinchona Alkaloids And Their Derivatives As Catalysts In Metal-Free Asymmetric Synthesis. Tetrahedron 2011, 67, 1725-1762. [CrossRef]

9. Poulsen, T.B.; Alemparte, C.; Saaby, S.; Bella, M.; Jørgensen, K.A. Direct Organocatalytic and Highly Enantioand Diastereoselective Mannich Reactions of $\alpha$-Substituted $\alpha$-Cyanoacetates. Angew. Chem. Int. Ed. 2005, 44, 2896-2899. [CrossRef] [PubMed]

10. Han, B.; Li, J.-L.; Xiao, Y.-C.; Zhou, S.-L.; Chen, Y.-C. Thiourea-Catalyzed Asymmetric Mannich-Type Reactions. Curr. Org. Chem. 2011, 15, 4128-4143. [CrossRef]

11. Hatano, M.; Ishihara, K. Highly Practical BINOL-Derived Acid-Base Combined Salt Catalysts for the Asymmetric Direct Mannich-Type Reaction. Synthesis 2010, 2010, 3785-3801. [CrossRef]

12. Smith, A.B.; Kanoh, N.; Minakawa, N.; Rainier, J.D.; Blase, F.R.; Hartz, R.A. Tremorgenic Indole Alkaloids. Studies Directed toward the Assembly of the A, F, and I Rings of Penitrem D: Observation of an Unexpected Stereochemical Outcome. Org. Lett. 1999, 1, 1263-1266. [CrossRef] [PubMed]

13. Akiyama, T. 6.3 C-C Bond Formation: Mannich Reaction. In Comprehensive Chirality; Elsevier: Amsterdam, The Netherlands, 2012; pp. 69-96, ISBN 978-0-08-095168-3.

14. Hong, L.; Wang, R. Recent Advances in Asymmetric Organocatalytic Construction of 3,3'-Spirocyclic Oxindoles. Adv. Synth. Catal. 2013, 355, 1023-1052. [CrossRef]

15. Ball-Jones, N.R.; Badillo, J.J.; Franz, A.K. Strategies for the Enantioselective Synthesis of Spirooxindoles. Org. Biomol. Chem. 2012, 10, 5165-5181. [CrossRef] [PubMed]

16. Trost, B.M.; Brennan, M.K. Asymmetric Syntheses of Oxindole and Indole Spirocyclic Alkaloid Natural Products. Synthesis 2009, 2009, 3003-3025. [CrossRef] 
17. Marti, C.; Carreira, E.M. Construction of Spiro[pyrrolidine-3,3'-oxindoles]-Recent Applications to the Synthesis of Oxindole Alkaloids. Eur. J. Org. Chem. 2003, 2003, 2209-2219. [CrossRef]

18. Galliford, C.V.; Scheidt, K.A. Pyrrolidinyl-Spirooxindole Natural Products as Inspirations for the Development of Potential Therapeutic Agents. Angew. Chem. Int. Ed. 2007, 46, 8748-8758. [CrossRef] [PubMed]

19. Tan, Y.; Feng, E.-L.; Sun, Q.-S.; Lin, H.; Sun, X.; Lin, G.-Q.; Sun, X.-W. Enantioselective synthesis of spirooxindole benzoquinolizines via organo-catalyzed cascade reactions. Org. Biomol. Chem. 2017, 15, 778-781. [CrossRef] [PubMed]

20. Zhi, Y.; Zhao, K.; Liu, Q.; Wang, A.; Enders, D. Asymmetric Synthesis of Functionalized Trifluoromethyl-Substituted Pyrrolidines Via an Organocatalytic Domino Michael/Mannich [3 + 2] Cycloaddition. Chem. Commun. 2016, 52, 14011-14014. [CrossRef] [PubMed]

21. Li, X.; Li, J. Recent Advances in the Development of MMPIs and APNIs Based on the Pyrrolidine Platforms. Mini Rev. Med. Chem. 2010, 10, 794-805. [CrossRef] [PubMed]

22. O'Hagan, D. Pyrrole, Pyrrolidine, Pyridine, Piperidine and Tropane Alkaloids. Nat. Prod. Rep. 2000, 17, 435-446. [CrossRef] [PubMed]

23. Fukui, H.; Shibata, T.; Naito, T.; Nakano, J.; Maejima, T.; Senda, H.; Iwatani, W.; Tatsumi, Y.; Suda, M.; Arika, T. Synthesis and Antibacterial Activity of Novel 7-(3-Substituted-3 or 4-Trifluoromethyl-1-Pyrrolidinyl)-8-Methoxyfluoroquinolones. Bioorg. Med. Chem. Lett. 1998, 8, 2833-2838. [CrossRef]

24. Jlalia, I.; Lensen, N.; Chaume, G.; Dzhambazova, E.; Astasidi, L.; Hadjiolova, R.; Bocheva, A.; Brigaud, T. Synthesis of an MIF-1 Analogue Containing Enantiopure (S)- $\alpha$-Trifluoromethyl-Proline and Biological Evaluation on Nociception. Eur. J. Med. Chem. 2013, 62, 122-129. [CrossRef] [PubMed]

25. Yu, J.-S.; Zhou, J. Organocatalytic Enantioselective Mukaiyama-Mannich Reaction of Fluorinated Enol Silyl Ethers and Cyclic N-sulfonyl Ketimines. Org. Chem. Front. 2016, 3, 298-303. [CrossRef]

26. Oppolzer, W.; Wills, M.; Kelly, M.J.; Signer, M.; Blagg, J. Chiral Toluene-2, $\alpha$-sultam Auxiliaries: Asymmetric Diels-Alder Reactions of $N$-enoyl Derivatives. Tetrahedron Lett. 1990, 31, 5015-5018. [CrossRef]

27. Takeuchi, Y.; Suzuki, T.; Satoh, A.; Shiragami, T.; Shibata, N. N-Fluoro-3-cyclohexyl-3methyl-2,3-dihydrobenzo[1,2- $d$ ] isothiazole 1,1-Dioxide: An Efficient Agent for Electrophilic Asymmetric Fluorination of Enolates. J. Org. Chem. 1999, 64, 5708-5711. [CrossRef] [PubMed]

28. Sun, H.M.; Liu, Z.P.; Tang, L.Q. Synthesis of Novel Chiral Fluorinating Agents, (+)- and (-)-N-fluoro-3-methyl-3-(4-methylphenyl)-2H-benzo[e][1,2]thiazine-1,1,4-triones. Chin. Chem. Lett. 2008, 19, 907-910. [CrossRef]

29. Davis, F.A.; Chen, B.C. Asymmetric Hydroxylation of Enolates with N-sulfonyloxaziridines. Chem. Rev. 1992, 92, 919-934. [CrossRef]

30. Zhang, S.; Li, L.; Hu, Y.; Zha, Z.; Wang, Z.; Loh, T.-P. Bifunctional Amino Sulfonohydrazide Catalyzed Direct Asymmetric Mannich Reaction of Cyclic Ketimines with Ketones: Highly Diastereo- and Enantioselective Construction of Quaternary Carbon Stereocenters. Org. Lett. 2015, 17, 1050-1053. [CrossRef] [PubMed]

31. Wrobel, J.; Dietrich, A.; Woolson, S.A.; Millen, J.; McCaleb, M.; Harrison, M.C.; Hohman, T.C.; Sredy, J.; Sullivan, D. Novel Spirosuccinimides with Incorporated Isoindolone and Benzisothiazole 1,1-Dioxide Moieties as Aldose Reductase Inhibitors and Antihyperglycemic Agents. J. Med. Chem. 1992, 35, 4613-4627. [CrossRef] [PubMed]

32. Drabina, P.; Harmand, L.; Sedlak, M. Enantioselective Henry Reaction Catalyzed by Supported Transition Metal Complexes. Curr. Org. Synth. 2014, 11, 879-888. [CrossRef]

33. Boruwa, J.; Gogoi, N.; Saikia, P.P.; Barua, N.C. Catalytic asymmetric Henry reaction. Tetrahedron Asymmetry 2006, 17, 3315-3326. [CrossRef]

34. Luzzio, F.A. The Henry reaction: Recent examples. Tetrahedron 2001, 57, 915-945. [CrossRef]

35. Sasai, H.; Suzuki, T.; Arai, S.; Arai, T.; Shibasaki, M. Basic Character of Rare Earth Metal Alkoxides. Utilization in Catalytic Carbon-Carbon Bond-Forming Reactions and Catalytic Asymmetric Nitroaldol Reactions. J. Am. Chem. Soc. 1992, 114, 4418-4420. [CrossRef]

36. Yamada, K.-I.; Harwood, S.J.; Groger, H.; Shibasaki, M. The First Catalytic Asymmetric Nitro-Mannich-Type Reaction Promoted by a New Heterobimetallic Complex. Angew. Chem. Int. Ed. 1999, 38, 3504-3506. [CrossRef] 
37. Phillips, A.M.F. Recent Advances on the Organocatalytic Asymmetric Aza-Henry Reaction. Curr. Organocatal. 2016, 3, 222-242. [CrossRef]

38. Sukhorukov, A.Y.; Sukhanova, A.A.; Zlotin, S.G. Stereoselective Reactions of Nitro Compounds in the Synthesis of Natural Compound Analogs and Active Pharmaceutical Ingredients. Tetrahedron 2016, 72, 6191-6281. [CrossRef]

39. Alegre-Requena, J.V.; Marqués-López, E.; Herrera, R.P. Trifunctional Squaramide Catalyst for Efficient Enantioselective Henry Reaction Activation. Adv. Synth. Catal. 2016, 358, 1801-1809. [CrossRef]

40. Huang, J.-R.; Sohail, M.; Taniguchi, T.; Monde, K.; Tanaka, F. Formal (4+1) Cycloaddition and Enantioselective Michael-Henry Cascade Reactions To Synthesize Spiro[4,5]decanes and Spirooxindole Polycycles. Angew. Chem. Int. Ed. 2017, 56, 5853-5857. [CrossRef] [PubMed]

41. Luo, H.; Yan, X.; Chen, L.; Li, Y.; Liu, N.; Yin, G. Enantioselective Catalytic Domino Aza-Michael-Henry Reactions: One-Pot Asymmetric Synthesis of 3-Nitro-1,2-dihydroquinolines via Iminium Activation. Eur. J. Org. Chem. 2016, 2016, 1702-1707. [CrossRef]

42. Ashokkumar, V.; Duraimurugan, K.; Siva, A. A New Series of Bipyridine Based Chiral Organocatalysts for Enantioselective Henry Reaction. New J. Chem. 2016, 40, 7148-7156. [CrossRef]

43. Cruz-Acosta, F.; de Armas, P.; García-Tellado, F. Water-Compatible Hydrogen-Bond Activation: A Scalable and Organocatalytic Model for the Stereoselective Multicomponent Aza-Henry Reaction. Chem. Eur. J. 2013, 19, 16550-16554. [CrossRef] [PubMed]

44. Arai, T.; Suzuki, T.; Inoue, T.; Kuwano, S. Chiral Bis(imidazolidine)iodobenzene (I-Bidine) Organocatalyst for Thiochromane Synthesis Using an Asymmetric Michael/Henry Reaction. Synlett 2017, 28, $122-127$. [CrossRef]

45. Ping, X.-N.; Wei, P.-S.; Zhu, X.-Q.; Xie, J.-W. Catalyst-Controlled Switch in Diastereoselectivities: Enantioselective Construction of Functionalized 3,4-Dihydro-2H-thiopyrano[2,3- $b$ ]quinolines with Three Contiguous Stereocenters. J. Org. Chem. 2017, 82, 2205-2210. [CrossRef] [PubMed]

46. Mulchin, B.J.; Newton, C.G.; Baty, J.W.; Grasso, C.H.; Martin, W.J.; Walton, M.C.; Dangerfield, E.M.; Plunkett, C.H.; Berridge, M.V.; Harper, J.L.; et al. The Anti-cancer, Anti-inflammatory and Tuberculostatic Activities of a Series of 6,7-Substituted-5,8-quinolinequinones. Bioorg. Med. Chem. 2010, 18, 3238-3251. [CrossRef] [PubMed]

47. Kidwai, M.; Bhushan, K.R.; Sapra, P.; Saxena, R.K.; Gupta, R. Alumina-supported Synthesis of Antibacterial Quinolines Using Microwaves. Bioorg. Med. Chem. 2000, 8, 69-72. [CrossRef]

48. Quaglia, W.; Pigini, M.; Piergentili, A.; Giannella, M.; Gentili, F.; Marucci, G.; Carrieri, A.; Carotti, A.; Poggesi, E.; Leonardi, A.; et al. Structure-Activity Relationships in 1,4-Benzodioxan-Related Compounds. 7. Selectivity of 4-Phenylchroman Analogues for $\alpha 1$-Adrenoreceptor Subtypes. J. Med. Chem. 2002, 45, 1633-1643. [CrossRef] [PubMed]

49. Van Vliet, L.A.; Rodenhuis, N.; Dijkstra, D.; Wikström, H.; Pugsley, T.A.; Serpa, K.A.; Meltzer, L.T.; Heffner, T.G.; Wise, L.D.; Lajiness, M.E.; et al. Synthesis and Pharmacological Evaluation of Thiopyran Analogues of the Dopamine $D_{3}$ Receptor-Selective Agonist (4aR,10bR)-(+)-trans-3,4,4a,10b-Tetrahydro-4-n-propyl-2H,5H-[1]benzopyrano[4,3-b]-1,4-oxazin-9-ol (PD 128907). J. Med. Chem. 2000, 43, 2871-2882. [CrossRef] [PubMed]

50. Kaur, K.; Jain, M.; Reddy, R.P.; Jain, R. Quinolines and Structurally Related Heterocycles as Antimalarials. Eur. J. Med. Chem. 2010, 45, 3245-3264. [CrossRef] [PubMed]

51. Shiraki, H.; Kozar, M.P.; Melendez, V.; Hudson, T.H.; Ohrt, C.; Magill, A.J.; Lin, A.J. Antimalarial Activity of Novel 5-Aryl-8-Aminoquinoline Derivatives. J. Med. Chem. 2011, 54, 131-142. [CrossRef] [PubMed]

52. Grayson, M.N.; Houk, K.N. Cinchona Urea-Catalyzed Asymmetric Sulfa-Michael Reactions: The Brønsted Acid-Hydrogen Bonding Model. J. Am. Chem. Soc. 2016, 138, 9041-9044. [CrossRef] [PubMed]

53. Li, H.; Wang, Y.; Tang, L.; Deng, L. Highly Enantioselective Conjugate Addition of Malonate and $\beta$-Ketoester to Nitroalkenes: Asymmetric $\mathrm{C}-\mathrm{C}$ Bond Formation with New Bifunctional Organic Catalysts Based on Cinchona Alkaloids. J. Am. Chem. Soc. 2004, 126, 9906-9907. [CrossRef] [PubMed]

54. Li, H.; Wang, B.; Deng, L. Enantioselective Nitroaldol Reaction of $\alpha$-Ketoesters Catalyzed by Cinchona Alkaloids. J. Am. Chem. Soc. 2006, 128, 732-733. [CrossRef] [PubMed]

55. Wei, P.-S.; Wang, M.-X.; Xu, D.-C.; Xie, J.-W. Synthesis of 2,3-Dihydrothieno(2,3-b)quinolines and Thieno(2,3-b)- Quinolines Via an Unexpected Domino Aza-MBH/Alkylation/Aldol Reaction. J. Org. Chem. 2016, 81, 1216-1222. [CrossRef] [PubMed] 
56. Chen, Y.; Liu, X.; Luo, W.; Lin, L.; Feng, X. Asymmetric Organocatalytic Michael/Michael/Henry Sequence to Construct Cyclohexanes with Six Vicinal Stereogenic Centers. Synlett 2017, 28, 966-969. [CrossRef]

57. Mao, Z.; Jia, Y.; Xu, Z.; Wang, R. Asymmetric Organocatalytic Cascade Michael/Michael/Henry Reaction Sequence: Control of All Stereocenters in One Cyclohexane Skeleton. Adv. Synth. Catal. 2012, 354, 1401-1406. [CrossRef]

58. Shi, D.; Xie, Y.; Zhou, H.; Xia, C.; Huang, H. A Highly Diastereo- and Enantioselective Reaction for Constructing Functionalized Cyclohexanes: Six Contiguous Stereocenters in One Step. Angew. Chem. Int. Ed. 2012, 51, 1248-1251. [CrossRef] [PubMed]

59. Möhlmann, L.; Chang, G.-H.; Madhusudhan Reddy, G.; Lee, C.-J.; Lin, W. Organocatalytic Enantioselective Synthesis of Tetrahydrofluoren-9-ones via Vinylogous Michael Addition/Henry Reaction Cascade of 1,3-Indandione-Derived Pronucleophiles. Org. Lett. 2016, 18, 688-691. [CrossRef] [PubMed]

60. Cragoe, E.J., Jr.; Marangos, P.J.; Weimann, T.R. Medical Use of Fluorenone Derivatives for Treating and Preventing Brain and Spinal Injury. U.S. Patent 6,251,898 B1, 26 June 2011.

61. Raja, A.; Hong, B.-C.; Liao, J.-H.; Lee, G.-H. Organocatalytic Enantioselective Michael-Michael-Henry Reaction Cascade. An Entry to Highly Functionalized Hajos-Parrish-Type Ketones with Five to Six Contiguous Stereogenic Centers and Two Quaternary Carbons. Org. Lett. 2016, 18, 1760-1763. [CrossRef] [PubMed]

62. Eagan, J.M.; Hori, M.; Wu, J.; Kanyiva, K.S.; Snyder, S.A. Synthesis and Applications of Hajos-Parrish Ketone Isomers. Angew. Chem. Int. Ed. 2015, 54, 7842-7846. [CrossRef] [PubMed]

63. Eder, U.; Sauer, G.; Wiechert, R. New Type of Asymmetric Cyclization to Optically Active Steroid CD Partial Structures. Angew. Chem. Int. Ed. Engl. 1971, 10, 496-497. [CrossRef]

64. Hajos, Z.G.; Parrish, D.R. Asymmetric Synthesis of Bicyclic Intermediates of Natural Product Chemistry. J. Org. Chem. 1974, 39, 1615-1621. [CrossRef]

65. Palomo, C.; Oiarbide, M.; García, J.M. Current Progress in the Asymmetric Aldol Addition Reaction. Chem. Soc. Rev. 2004, 33, 65-75. [CrossRef] [PubMed]

66. Saito, S.; Yamamoto, H. Design of Acid-Base Catalysis for the Asymmetric Direct Aldol Reaction. Acc. Chem. Res. 2004, 37, 570-579. [CrossRef] [PubMed]

67. Alcaide, B.; Almendros, P. The Direct Catalytic Asymmetric Aldol Reaction. Eur. J. Org. Chem. 2002, 2002, 1595-1601. [CrossRef]

68. Heravi, M.M.; Zadsirjan, V.; Dehghani, M.; Hosseintash, N. Current Applications of Organocatalysts in Asymmetric Aldol Reactions: An Update. Tetrahedron Asymmetry 2017, 28, 587-707. [CrossRef]

69. Mase, N.; Hayashi, Y. 2.07 The Aldol Reaction: Organocatalysis Approach. In Comprehensive Organic Synthesis II, 2nd ed.; Knochel, P., Ed.; Elsevier: Amsterdam, The Netherlands, 2014; pp. 273-339, ISBN 978-0-08-097743-0.

70. Bhanushali, M.; Zhao, C.-G. Developing Novel Organocatalyzed Aldol Reactions for the Enantioselective Synthesis of Biologically Active Molecules. Synthesis 2011, 2011, 1815-1830. [CrossRef] [PubMed]

71. Schneider, C.; Boomhoff, M. Aldol Reactions in Domino Processes. In Domino Reactions; Tietze, L.F., Ed.; Wiley-VCH Verlag GmbH \& Co. KGaA: Weinheim, Germany, 2014; pp. 267-294, ISBN 978-3-527-67130-4.

72. Andrushko, V.; Andrushko, N. (Eds.) Stereoselective Synthesis of Drugs and Natural Products; Wiley: Hoboken, NJ, USA, 2013; ISBN 978-1-118-03217-6.

73. Meazza, M.; Potter, M.; Pitak, M.B.; Coles, S.J.; Mazzanti, A.; Rios, R. Highly Enantioselective Synthesis of Alkylpyridine Derivatives through a Michael/Michael/Aldol Cascade Reaction. Eur. J. Org. Chem. 2017, 2017, 719-725. [CrossRef]

74. Kumar, M.; Chauhan, P.; Valkonen, A.; Rissanen, K.; Enders, D. Asymmetric Synthesis of Functionalized Tricyclic Chromanes via an Organocatalytic Triple Domino Reaction. Org. Lett. 2017, 19, 3025-3028. [CrossRef] [PubMed]

75. Simon-Levert, A.; Arrault, A.; Bontemps-Subielos, N.; Canal, C.; Banaigs, B. Meroterpenes from the Ascidian Aplidium aff. densum. J. Nat. Prod. 2005, 68, 1412-1415. [CrossRef] [PubMed]

76. Garrido, L.; Zubía, E.; Ortega, M.J.; Salvá, J. New Meroterpenoids from the Ascidian Aplidium conicum. J. Nat. Prod. 2002, 65, 1328-1331. [CrossRef] [PubMed]

77. Am Ende, C.W.; Zhou, Z.; Parker, K.A. Total Synthesis of ( \pm )-Bisabosqual A. J. Am. Chem. Soc. 2013, 135, 582-585. [CrossRef] [PubMed] 
78. Skrabek, R.Q.; Galimova, L.; Ethans, K.; Perry, D. Nabilone for the Treatment of Pain in Fibromyalgia. J. Pain 2008, 9, 164-173. [CrossRef] [PubMed]

79. Muhammad, I.; Li, X.-C.; Dunbar, D.C.; ElSohly, M.A.; Khan, I.A. Antimalarial (+)-trans-Hexahydrodibenzopyran Derivatives from Machaerium multiflorum. J. Nat. Prod. 2001, 64, 1322-1325. [CrossRef] [PubMed]

80. Muhammad, I.; Li, X.-C.; Jacob, M.R.; Tekwani, B.L.; Dunbar, D.C.; Ferreira, D. Antimicrobial and Antiparasitic (+)-trans-Hexahydrodibenzopyrans and Analogues from Machaerium multiflorum. J. Nat. Prod. 2003, 66, 804-809. [CrossRef] [PubMed]

81. Maity, R.; Gharui, C.; Sil, A.K.; Pan, S.C. Organocatalytic Asymmetric Michael/Hemiketalization/Retro-aldol Reaction of $\alpha$-Nitroketones with Unsaturated Pyrazolones: Synthesis of 3-Acyloxy Pyrazoles. Org. Lett. 2017, 19, 662-665. [CrossRef] [PubMed]

82. Fustero, S.; Sánchez-Roselló, M.; Barrio, P.; Simón-Fuentes, A. From 2000 to Mid-2010: A Fruitful Decade for the Synthesis of Pyrazoles. Chem. Rev. 2011, 111, 6984-7034. [CrossRef] [PubMed]

83. Schmidt, A.; Dreger, A. Recent Advances in the Chemistry of Pyrazoles. Properties, Biological Activities, and Syntheses. Curr. Org. Chem. 2011, 15, 1423-1463. [CrossRef]

84. Martín-Acosta, P.; Feresin, G.; Tapia, A.; Estévez-Braun, A. Microwave-Assisted Organocatalytic Intramolecular Knoevenagel/Hetero Diels-Alder Reaction with O-(Arylpropynyloxy)-Salicylaldehydes: Synthesis of Polycyclic Embelin Derivatives. J. Org. Chem. 2016, 81, 9738-9756. [CrossRef] [PubMed]

85. Peña, R.; Martín, P.; Feresin, G.E.; Tapia, A.; Machín, F.; Estévez-Braun, A. Domino Synthesis of Embelin Derivatives with Antibacterial Activity. J. Nat. Prod. 2016, 79, 970-977. [CrossRef] [PubMed]

86. Lu, H.; Wang, J.; Wang, Y.; Qiao, L.; Zhou, Y. Embelin and Its Role in Chronic Diseases. In Anti-inflammatory Nutraceuticals and Chronic Diseases; Advances in Experimental Medicine and Biology; Springer: Cham, Switzerland, 2016; pp. 397-418, ISBN 978-3-319-41332-7.

87. Enders, D.; Grossmann, A.; Gieraths, B.; Düzdemir, M.; Merkens, C. Organocatalytic One-Pot Asymmetric Synthesis of 4H,5H-Pyrano[2,3-c]pyrazoles. Org. Lett. 2012, 14, 4254-4257. [CrossRef] [PubMed]

88. Hong, B.-C.; Jan, R.-H.; Tsai, C.-W.; Nimje, R.Y.; Liao, J.-H.; Lee, G.-H. Organocatalytic Enantioselective Cascade Michael-Michael-Wittig Reactions of Phosphorus Ylides: One-Pot Synthesis of the all-cis Trisubstituted Cyclohexenecarboxylates via the $[1+2+3]$ Annulation. Org. Lett. 2009, 11, 5246-5249. [CrossRef] [PubMed]

89. Hazra, G.; Maity, S.; Bhowmick, S.; Ghorai, P. Organocatalytic, enantioselective synthesis of benzoxaboroles via Wittig/oxa-Michael reaction Cascade of $\alpha$-formyl boronic acids. Chem. Sci. 2017, 8, 3026-3030. [CrossRef] [PubMed]

90. Adamczyk-Woźniak, A.; Borys, K.M.; Sporzyński, A. Recent Developments in the Chemistry and Biological Applications of Benzoxaboroles. Chem. Rev. 2015, 115, 5224-5247. [CrossRef] [PubMed] 